\section{Author Index \\ Volume 9}

Abdul-Majid, Mariani, see Othman, Norfaizah Abdul-Rahman, Aisyah, see Othman, Norfaizah 3 (2018) 1850009

3 (2018) 1850009 Almahmood, Hassan, Munyif, Munif Al \& Willett, Thomas D., Most Speculative Attacks Do Not Succeed: Currency Crises and Currency Crashes

1 \& 2 (2018) 1850001

Bayraktutan, Yusuf \& Bidırd1, Hanife, Innovation and High-Tech Exports in Developed and Developing Countries

Bıdırd1, Hanife, see Bayraktutan, Yusuf

Forte, Rosa, see Silva, Vera

Ghosh, Sudeshna, Globalization and Environment: An Asian Experience

Gnangnon, Sèna Kimm, Donors' Trade and Their Supply of Development Aid Related to the Trade Sector: Does Donors' Output Gap Matter?

Gnangnon, Sèna Kimm, Multilateral Trade Liberalization and Terms of Trade Volatility Guo, Jiequn, Fair Value Adjusted Pricing of Mutual Funds Using Treasury Futures

Li, Jie \& Ouyang, Alice Y., Stock and Labor Market Synchronization and Income Inequality: Evidence from OECD Countries

Munyif, Munif Al, see Almahmood, Hassan

Othman, Norfaizah, Abdul-Majid, Mariani \& Abdul-Rahman, Aisyah, Determinants of Banking Crises in ASEAN Countries

Otsubo, Kansho Piotr, The Effects of Fiscal and Monetary Policies in Japan: What Combination of Policies Should Be Used?

Ouyang, Alice Y., see Li, Jie
3 (2018) 1850011

3 (2018) 1850011

1 \& 2 (2018) 1850005

3 (2018) 1850010

1 \& 2 (2018) 1850002

3 (2018) 1850007

1 \& 2 (2018) 1850006

1 \& 2 (2018) 1850003

1 \& 2 (2018) 1850001

3 (2018) 1850009

1 \& 2 (2018) 1850004

1 \& 2 (2018) 1850003 
Silva, Vera \& Forte, Rosa, The Impact of Foreign Direct Investment on Home Country Exports

$1 \& 2(2018) 1850005$

Vuignier, Renaud, Attracting Investments and

Companies: Federal Multi-Level Collaboration

in Switzerland and Canada

3 (2018) 1850008

Willett, Thomas D., see Almahmood, Hassan

$1 \& 2(2018) 1850001$ 